\title{
Ancient DNA analysis indicates the first English lions originated from North Africa
}

\author{
Ross Barnett ${ }^{1}$, Nobuyuki Yamaguchi², Beth Shapiro ${ }^{1}$, Richard Sabin ${ }^{3}$ \\ ${ }^{1}$ Henry Wellcome Ancient Biomolecules Centre, University of Oxford, South Parks Road, Oxford, OX1 3PS UK \\ ${ }^{2}$ Wildlife Conservation Research Unit, University of Oxford, Tubney House, Abingdon Road, Tubney, Abingdon, \\ OX13 5QL UK, nobuyuki.yamaguchi@zoo.ox.ac.uk; present address: Department of Biological Sciences, Univer- \\ sity of Qatar, P.O. Box 2713, Doha, Qatar, yamaguchi@qu.edu.qa (corresponding author) \\ ${ }^{3}$ Department of Zoology, Natural History Museum, Cromwell Road, London, SW7 5BD UK
}

Key words: Panthera leo, Barbary lion, medieval, Royal Menagerie, Tower of London

\begin{abstract}
The Royal Menagerie of England was established at the Tower of London in the $13^{\text {th }}$ Century and served as a home of exotic animals until it was closed on behalf of the Duke of Wellington in 1835. Two well-preserved lion skulls recovered from the moat of the Tower of London were recently radiocarbon-dated to AD 1280-1385 and AD 1420-1480, making them the earliest confirmed lion remains in the British Isles since the extinction of the Pleistocene cave lion. Using ancient DNA techniques and cranio-morphometric analysis, we identify the source of these first English lions to lie in North Africa, where no natural lion population remains today.
\end{abstract}

\section{Contents}

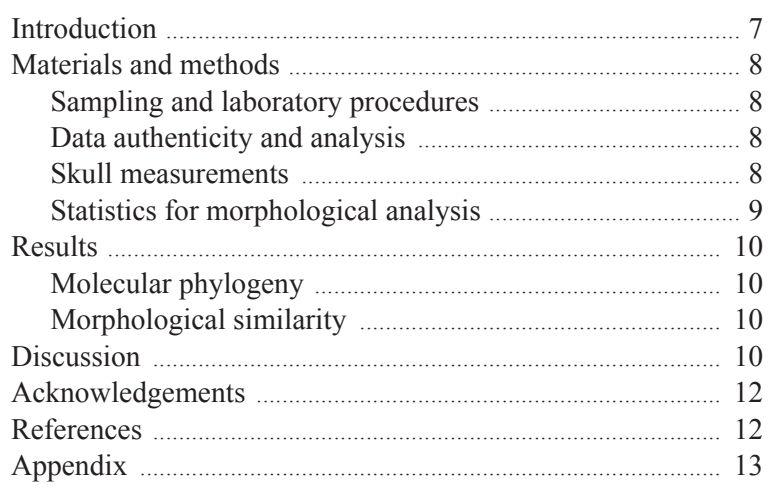

\section{Introduction}

The lion Panthera leo (Linnaeus, 1758) is a charismatic large cat that has been imported into Europe since early historic times. Lions were amongst the many exotic animals that were imported to Rome during the early Imperial Period for the gladiatorial games, although towards the end of the Roman Empire the increased scarcity of these animals in the wild forced combat shows to be largely replaced by exhibitions (Baratay and HardouinFugier, 2002). Exotic wild animals do not appear to have been kept regularly in western Europe until the $13^{\text {th }}$ century, when they were rediscovered through Western contact with the Byzantine and Muslim worlds (Baratay and Hardouin-Fugier, 2002). In England, the Royal Menagerie was established in $12^{\text {th }}-13^{\text {th }}$ centuries in Woodstock near Oxford, and slightly later was relocated to the Tower of London, where the first residents were three leopards sent to Henry III by the Holy Roman Emperor Frederick II in 1235 (Hahn, 2003).

Although the Royal Menagerie and its animals are known from documentary records, few physical remains survive (O'Regan et al., 2005). Amongst the rare exceptions are two lion skulls that were recovered from the moat of the Tower of London during excavations in 1936-1937. These skulls were recently radiocarbon-dated to AD1280-1385 and AD1420-1480, making them the earliest confirmed lion remains in the British Isles since the extinction of the Pleistocene cave lion (P. l. spelaea) (O'Regan et al., 2005). The discovery of these first English lions attracted significant media attention (BBC, 2005). However, the geographical origin of these animals has not yet been investigated. Such knowledge would provide novel insights not only into the history of the Royal Menagerie, but also into patterns of animal trafficking during the Medieval period. Direct animal trade between Europe and sub-Saharan Africa was not well developed until the $18^{\text {th }}$ century (Anonymus, 1876). Therefore, it may be reasonable to presume that the Tower lions were unlikely to have originated from sub-Saharan regions. Nevertheless, there is an undeniable possibility that sub-Saharan lions reached Europe as they could have 
reached shipping ports in North Africa and the Middle East through trans-Saharan trade routes that were well established by the early Medieval period (Yamaguchi, 2000b). Apart from a tiny population in northwest India, lions had been practically exterminated outside sub-Saharan Africa by the turn of the $20^{\text {th }}$ century (Yamaguchi and Haddane, 2002; Patterson, 2004). In this context, if the foregoing first hypothesis turned out to be the case, the Tower lion skulls would possess significant value for the history of the lion, as well as the history of Medieval England.

Recent advances in ancient DNA (aDNA) techniques (e.g. Shapiro et al., 2004), in association with the available data concerning genetic profiles of the lion across its natural range (Dubach et al., 2005; Barnett et al., 2006a, 2006b) have made it possible to identify the origins of unprovenanced lion specimens, such as the Tower lions (Barnett et al., 2007).

In this paper we use aDNA techniques to extract and amplify mitochondrial DNA (mtDNA) from the two Tower lions, and compare the results with those of Barnett et al. (2006a, 2006b). We also conduct a cranio-morphometric analysis to investigate which lion population the Tower lions are morphologically similar to. Then, by combining both molecular and morphological results, we will try to determine the geographic origin of the first lions in England.

\section{Materials and methods}

\section{Sampling and laboratory procedures}

Small pieces of cortical bone (c. $5 \times 5 \times 2 \mathrm{~mm}$ ) were sampled from the mandibles of the two Tower lion skulls (registration numbers NHM1952.10.20.15 and NHM1952.10.20.16) at the Natural History Museum, London, UK. Laboratory procedures were carried out as described in Barnett et al. (2006a) at the Henry Wellcome Ancient Biomolecules Centre (ABC), Oxford University, which is geographically isolated from modern molecular biology work and DNA amplification by polymerase chain reaction (PCR).

\section{Data authenticity and analysis}

Extraction of specimens NHM1952.10.20.15 and NHM 1952.10.20.16 took place in the $\mathrm{ABC}$ and was performed along with negative extraction controls. PCR amplification of a small hypervariable fragment of the mitochondrial control region was performed twice for each sample, each time incorporating negative amplification controls. The four resulting amplification products were then cloned using the TOPO TA system (Invitrogen, Carlsbad CA USA), sequenced on ABI377 automated sequencers (Perkin-Elmer, Wellesley MA USA), and aligned with previously published lion sequences (Barnett et al., 2006a, 2006b). A summary of the cloning results is presented in the Appendix. A total of 12 clones were sequenced from sample NHM 1952.10.20.15, and 10 from NHM1952. 10.20.16. Of these, only three sequences show evidence of postmortem DNA damage (E4, E6, and F5 in Table S1) and, in each instance, the damage occurs at nucleotide sites that are not known to be polymorphic in lions. A medianjoining network was constructed from the resulting sequences using Network v4.1.0.3 (Bandelt et al., 1999).

\section{Skull measurements}

To investigate the origins of the Tower lions independently of the molecular results, morphological investigation was undertaken using Asiatic and North African Barbary lion skulls kept in natural history collections in the UK and Europe. A skull was classified as subadult if cemento-enamel junctions of all canines were already visible above the alveoli of the cleaned skull and yet the basioccipital-basisphenoid suture, and/or frontal suture, was still open. If those sutures were closed, a skull was classified adult. Seventy five craniometric measurements were taken of the cranium and mandible, modified from Yamaguchi et al. (2004), using a metal caliper to the nearest $0.02 \mathrm{~mm}$, except for those of 10 larger variables that were measured to the nearest $0.05 \mathrm{~mm}$ using a larger metal calliper (for details see Appendix). To test the measurement errors, five skulls were randomly selected and each measurement was taken three times on each skull. The coefficient of variation for each of the 75 variables was calculated, and the variables with average coefficient of variations of more than $2 \%$ were excluded from the analysis by accepting the arbitrary cut-off line for reliability and consistency in measurements used in Yamaguchi et al. (2004) (see Appendix). We have measured all Asiatic and North African Barbary lion skulls kept, and available for measurement, in major natural history collections in the UK and Europe. However, as not every skull was intact, some variables were excluded from the analysis for maximising both Asiatic and North African Barbary lion specimens to be included into the analysis whilst retaining as many variables as possible. We retained 57 variables with 23 individuals (Table 1). 


\section{Statistics for morphological analysis}

All statistical analyses were carried out using the SPSS statistics package (version 13: SPSS Inc., Chicago, USA). A principal component analysis (PCA) was carried out to reduce the numbers of variables for the subsequent analyses, which were based on extracted principal components whose eigenvalues were larger than 1 (Tabachnick and Fidell, 2007). Then, a discriminant analyses (DA) was carried out to investigate if Asiatic and North African Barbary lion skulls could be distinguished, with the prior probabilities computed from the group sizes. A DA is designed to develop classification functions to classify each specimen best by following $a$ priori groupings, so that it will usually result in a fairly good discrimination between the groups (Tabachnick and Fidell, 2007). Therefore, a cross-validation test was also carried out to check which group each case would be classified into if it was classified by the func- tions derived from all cases other than itself. Then, we tested if the Tower lions would be classified as either Asiatic or North African Barbary, or both.

In addition to sexual size dimorphism that is common in the Felidae, it has been suggested that the skull morphological characteristics of captive lions differ from those of wild animals (Hollister, 1917). While a preliminary morphometric analysis suggested that both Tower lions were males based on the greatest length of skull and canine size (Gittleman and Van Valkenburgh, 1997), specimens did not have their sex recorded. Additionally, the specimens had spent at least some time in captivity. We therefore included into the analysis both male and female, and both captive and wild, individuals in our comparative data set (see Table 1). We deliberately did so to find out if a discriminant analysis (DA) would be able to separate the North African Barbary lion from the Asiatic lion regardless of sex and whether an animal was captive or wild.

Table 1. Lion skulls used for the morphological analysis. Museums are Natural History Museum London, Muséum National d'Histoire Naturelle Paris, Museum für Naturkunde der Humboldt-Universität, Berlin, Natural History Museum, University of Oxford, Forschungsinstitut und Naturmuseum Senckenberg, Frankfurt, Musée Zoologique, Strasbourg, and female is indicated by (f), male (m), adult (a), and subadult (sa). Individual ID numbers (e.g. P1, L1 or T1) are corresponding to those in Fig 2.

\begin{tabular}{|c|c|c|c|c|c|c|}
\hline subspecies & sex & age & origin & museum & museum ID & comments \\
\hline \multicolumn{7}{|c|}{ Panthera leo persica } \\
\hline$\overline{\mathrm{P} 1}$ & f & $\mathrm{a}$ & India & London & 1931.4.13.2 & wild \\
\hline $\mathrm{P} 2$ & $\mathrm{f}$ & $\mathrm{a}$ & India & London & 1945.136 & captive \\
\hline P3 & $\mathrm{f}$ & $\mathrm{a}$ & India & London & 1857.2.24.1 & captive \\
\hline $\mathrm{P} 4$ & $\mathrm{f}$ & $\mathrm{a}$ & India & Oxford & 14174 & wild \\
\hline P5 & $\mathrm{f}$ & $\mathrm{a}$ & India & Paris & A-1884 & captive \\
\hline P6 & $\mathrm{f}$ & $\mathrm{a}$ & India & Paris & $\mathrm{I}-1460$ & captive \\
\hline P7 & $\mathrm{f}$ & $\mathrm{a}$ & Iran & Paris & 1962.2847 & captive \\
\hline P8 & $\mathrm{m}$ & $\mathrm{a}$ & India & London & 1930.6.6.1 & wild \\
\hline P9 & $\mathrm{m}$ & a & India & London & 1931.1.5.1 & wild \\
\hline $\mathrm{P} 10$ & $\mathrm{~m}$ & $\mathrm{a}$ & India & London & 1931.1.5.2 & wild \\
\hline P11 & $\mathrm{m}$ & $\mathrm{a}$ & India & London & 1931.4.13.1 & wild \\
\hline P12 & $\mathrm{m}$ & $\mathrm{a}$ & India & Paris & 1873.556 & captive \\
\hline P13 & $\mathrm{m}$ & $\mathrm{a}$ & Asia? & Frankfurt & 1366 & captive? \\
\hline P14 & $\mathrm{m}$ & $\mathrm{a}$ & Iran & Paris & 1962.2854 & captive \\
\hline \multicolumn{7}{|l|}{ P.l.leo } \\
\hline$\overline{\mathrm{L} 1}$ & $\mathrm{f}$ & $\mathrm{a}$ & Algeria & Paris & A-1873 & captive \\
\hline $\mathrm{L} 2$ & $\mathrm{f}$ & $\mathrm{a}$ & Algeria & Paris & 1862.54 & captive \\
\hline L3 & $\mathrm{f}$ & $\mathrm{a}$ & N. Africa & Berlin & 15960 & captive \\
\hline L4 & $\mathrm{f}$ & $\mathrm{a}$ & N. Africa & Frankfurt & 15766 & captive \\
\hline L5 & $\mathrm{f}$ & $\mathrm{a}$ & N. Africa & Strasbourg & 939 & captive \\
\hline L6 & $\mathrm{m}$ & $\mathrm{a}$ & N. Africa & Paris & A-7912 & captive \\
\hline L7 & $\mathrm{m}$ & $\mathrm{a}$ & N. Africa & Paris & 1882.502 & captive \\
\hline \multicolumn{7}{|l|}{ Tower lion } \\
\hline$\overline{\mathrm{T} 1}$ & & $\mathrm{a}$ & & London & NHM1952.10.20.15 & captive \\
\hline $\mathrm{T} 2$ & & sa & & London & NHM1952.10.20.16 & captive \\
\hline
\end{tabular}


Table 2. Classification results obtained by a discriminant analysis. The only one misclassified case in the cross-validation test was P6 in Table 1.

\begin{tabular}{lll}
\hline Original classifications & Predicted classifications \\
\hline P. l. persica & Panthera leo persica & P. l. leo \\
P. l. leo & 14 & 0 \\
\hline P.l. persica & 0 & 7 \\
P. l. leo & Cross-validation & \\
\hline & 13 & 1 \\
1952.10 .20 .15 & 0 & 7 \\
1952.10 .20 .16 & 0 & 1 \\
\hline
\end{tabular}

\section{Results}

\section{Molecular phylogeny}

Approximately $130 \mathrm{bp}$ of the mtDNA control region (HVR1) was amplified from both samples. Although the Felidae are known to contain macrosatellites (numts) resulting from nuclear translocation of the mtDNA (Cracraft et al., 1998; Lopez et al., 1997), visual comparison of the sequences obtained from the Tower lions with previously published numts and lion mitochondrial sequences clearly indicated that the Tower lion sequences were indeed mitochondrial (for details see Barnett et al., 2006a, b). Median-joining network analysis clarified that both consensus clone sequences were identical to the unique haplotype of the North African Barbary lion out of the 11 distinct haplotypes previously identified in the lion (Barnett et al., 2007). The sequences obtained from the Tower lions were also distinguishable from two haplotypes that characterised lions from India and Iran, which were the next most closely related haplotypes (Barnett et al., 2006a, b).

\section{Morphological similarity}

A PCA based on the retained 57 variables resulted in seven principal components. Then, a DA based on those seven principal components extracted one canonical discriminant function, which was used in the analysis. The DA successfully separated Asiatic and North African Barbary lions, and the cross-validation test classified most (20 out of 21 ) specimens into the right groups (Table 2). The two Tower lions were both classified as the North African Barbary lion (Table 2 and Fig. 1).

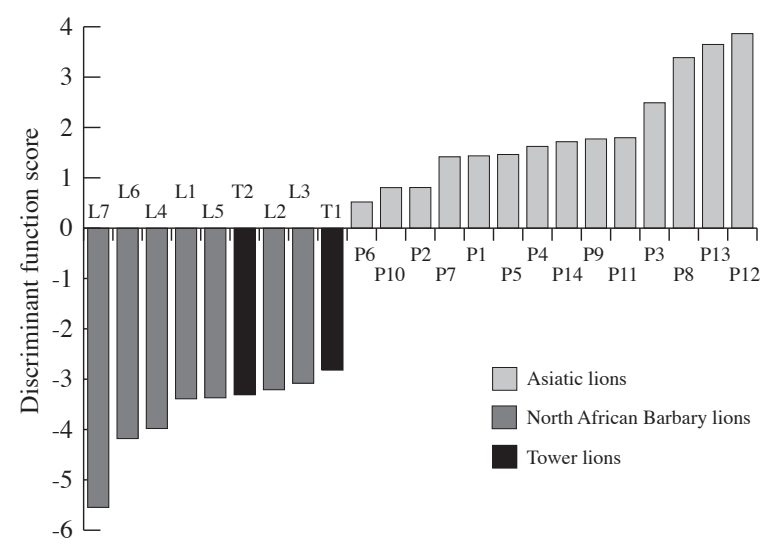

Fig. 1. Discriminant function scores of the specimens analysed. Individual ID numbers are corresponding to those in Table 1. Note that the discriminant function was extracted to distinguish lions from Asia and North Africa, and not to separate sexes. Therefore, although both the Tower lions place themselves amongst female Barbary lions, this does not indicate that they are females.

\section{Discussion}

Our results demonstrate that the two Tower lions share a unique mtDNA haplotype with the North African Barbary lion. Whilst written records have previously suggested that most lions brought into Medieval Europe originated from the region between North Africa and India (Anonymus, 1769; Baratay and HardouinFugier, 2002), such records have not been able to distinguish lions which actually originated from North Africa and lions that had been brought from sub-Saharan Africa and then shipped to Europe from North African ports. Our results are the first genetic evidence to clearly confirm that the former was the case.

Previous work has shown that lions inhabiting the extensive stretch of land between northwest Africa and India are very closely related: characterised by a simple mtDNA haplotype structure, in particular in comparison to the ancestral population in sub-Saharan Africa, with the distance between the former and the latter being three to seven substitutions whilst only less than two within the former (Barnett et al., 2006a). Amongst the North African - Asian lion populations, our results (both genetic and morphological) suggest that the Tower lions belong to the North African Barbary lion in comparison to those originating from India and Iran. 


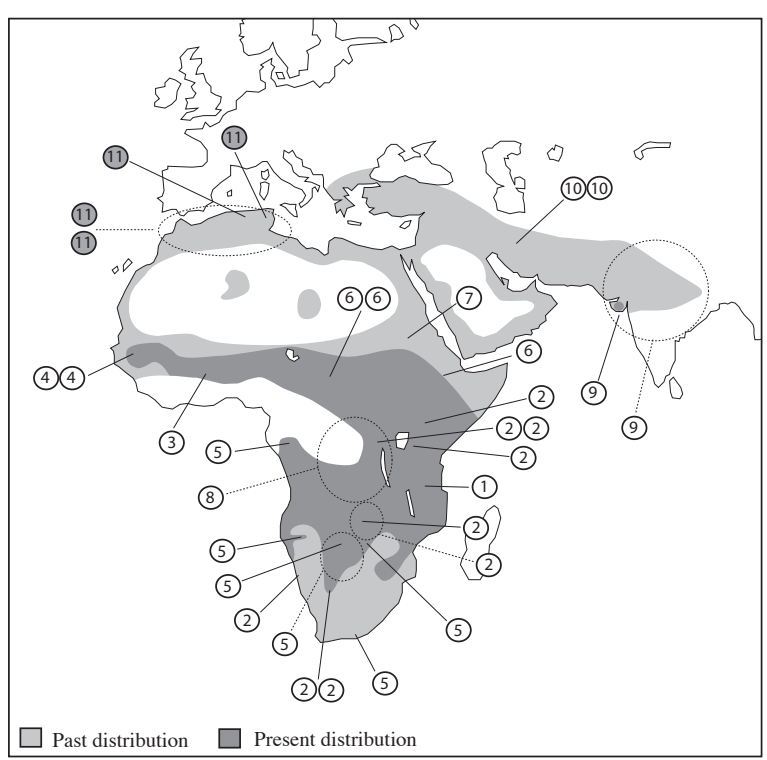

Fig. 2. Map showing approximate sampling sites of the lion specimens analysed in Barnett et al. (2006a, b), with mtDNA haplotypes (see Table 1). If the exact sampling location is not known, a dashed circle and dashed line are used. Two Tower lions possess the haplotype-11 that is unique to, and invariable within, the North African Barbary lion.

We expected that the skull morphometric analysis would not clearly separate North African Barbary lions from Asiatic lions if we included all the skulls measured into the analysis. This was because the wellknown sexual dimorphism (e.g. Gittleman and Van Valkenburgh, 1997) and morphological difference between wild and captive individuals (Hollister, 1917) might make a clear-cut separation of the two geographic populations unlikely. Nevertheless, the discriminant analysis (DA) succeeded in doing so, suggesting that those two geographic populations would be distinguished from each other regardless of sex and whether an animal was wild or captive. We have not overlooked that the two Tower lions, which are likely to be males, appear amongst female Barbary lions in Figure 1. However, the DA was carried out to investigate if North African Barbary lions could be separated from Asiatic lions, and vice versa, and therefore, the analysis was not optimised for separating sexes.

Unfortunately, in spite of our extensive search across major natural history collections in Europe, Russia, Central Asia, and North America, no lion sample has been identified from the region between Libya and Iraq, from which lions totally disappeared by the mid $20^{\text {th }}$ century (Nowell and Jackson, 1996; Patterson, 2004) although lions originated from that region were apparently imported into Europe during the $19^{\text {th }}$ century (Edwards, 1996; Jardine, 1834). This makes it impossible to determine either mtDNA haplotype(s) or quantitative morphological characteristics that were present in this region, and potentially complicating the identification of the geographic origin of the Tower lions.

Historic records suggest that a single, contiguous population of lions existed from North Africa through the Middle East to India until the growth of civilisations along the Egyptian Nile and Sinai Peninsula (the narrow connection between Africa and Eurasia) some 4,000 years ago. The development of a human-dominated, narrow, land bridge effectively severed gene flow between North Africa and Near East Asia, which are also separated by more than $4,000 \mathrm{~km}$ of arid land (Nowell and Jackson, 1996; Yamaguchi, 2000a), and isolated lion populations to the west and east of this barrier. In the Near East, lions survived in southeastern Turkey until 1870, northern Syria (up until c. 1890s) and Iraq (the last record was in 1918) (Nowell and Jackson, 1996; Patterson, 2004). As we mentioned above, no genetic/quantitative morphological information is known for these eastern lions because no provenanced specimen is known to exist for investigation. However, their geographic proximity to lions in Iran (Nowell and Jackson, 1996), and their isolation from lion populations further west, may suggest that they are likely to belong to the Iranian haplotype (as well as Iranian/Indian morphological group), rather than those of the North African Barbary, and were not the source of the Tower lions.

Arid conditions in the eastern part of North Africa (Libya and Egypt) limited the size of the lion population in this region, even prior to the early $18^{\text {th }}$ century, when lions finally disappeared from the eastern North African Mediterranean littoral zone (Nowell and Jackson, 1996; Yamaguchi and Haddane, 2002). Western North Africa (Morocco, Algeria and Tunisia), on the other hand, supported a relatively large lion population until fairy recently, and was one of the most important regions to supply lions to Europe between the $17^{\text {th }}$ and first half of the $19^{\text {th }}$ centuries (Anonymus, 1769; Yamaguchi and Haddane, 2002). Furthermore, western North Africa was the nearest region to Europe to sustain lion populations until the early $20^{\text {th }}$ century, making it an obvious and practical source for medieval merchants. The foregoing argument may suggest that, while further evidence will be required to draw a firm conclusion, the first English lions originated in North Africa - probably North-west Africa. 


\section{Acknowledgements}

We thank Paula Jenkins and Daphne Hills for providing access to samples. RB was supported by NERC and BS was supported by The Wellcome Trust. NY was supported by the European Union SYNTHESYS programme to visit Muséum National d'Histoire Naturelle, Paris, France, and Museum für Naturkunde der Humboldt-Universität, Berlin, Germany for skull measurements. We also thank Paula Jenkins, Daphne Hills, Louise Tomsett at Natural History Museum, London, Malgosia NowakKemp at Natural History Museum, University of Oxford, Oxford, UK, Robert Asher, Peter Giere, Irene Thomas, Wolf-Dieter Heinrich at Museum für Naturkunde der Humboldt-Universität, Berlin, Katrin Krohmann, Thomas Martin at Forschungsinstitut und Naturmuseum Senckenberg, Frankfurt, Germany, Jacques Cuisin, Francis Renoud, Daniel Robineau, Michel Tranier at Muséum National d'Histoire Naturelle, Paris, MarieDominique Wandhammer, Virginia Rakotondrahaja at Musée Zoologique, Strasbourg, France, for their kind support during NY's visit to measure lion skulls. Two anonymous reviewers have contributed considerably with valuable comments, for which we are most thankful.

\section{References}

Anonymus 1769. A historical account of the curiosities of London and Westminster. London: Bible and Sun.

Anonymus 1876. The land of the lion. London: Seeley, Jackson, and Halliday.

Bandelt HJ, Forster P, Rohl A. 1999. Median-joining networks for inferring intraspecific phylogenies. Moecular. Biology and Evolution 16: 37-48.

Barnett R, Yamaguchi N, Barnes I, Cooper A. 2006a. Lost population and preserving genetic diversity in the lion Panthera leo: implications for its ex situ conservation. Conservation Genetics 7: 507-514.

Barnett R, Yamaguchi N, Barnes I, Cooper A. 2006b. The origin, current diversity, and future conservation of the modern lion (Panthera leo). Proceedings of the Royal Society, Series BL Biological Science 273: 2119-2125.

Barnett R, Yamaguchi N, Shapiro B, Nijman V. 2007. Using ancient DNA techniques to identify the origin of unprovenanced museum specimens, as illustrated by the identification of a $19^{\text {th }}$ century lion from Amsterdam. Contributions to Zoology 76:87-94.

Baratay E, Hardouin-Fugier, E. 2002. Zoo: A history of zoological gardens in the West. London: Reaktion Books.

BBC 2005. Big cats prowled London's tower. http://news.bbc. co.uk/1/hi/sci/tech/4371908.stm [visited 24 October 2005].

Cracraft J, Feinstein J, Vaughn J, Helm-Bychowski K. 1998. Sorting out tigers (Panthera tigris): mitochondrial sequences, nuclear inserts, systematics, and conservation genetics. Animal Conservation 1: 139-150.

Dubach J, Patterson BD, Briggs MB, Venzke K, Flamand J, Stander P, Scheepers L, Kays RW. 2005. Molecular genetic variation across the southern and eastern geographic ranges of the African lion, Panthera leo. Conservation Genetics 6: $15-24$.

Edwards J. 1996. London Zoo from old photographs 1852-1914. London: John Edwards (printed by Edward Charles).

Gittleman JL, Van Valkenburgh B. 1997. Sexual dimorphism in the canines and skulls of carnivores: effects of size, phylogeny, and behavioural ecology. Journal of Zoology, London 242: 97-117.

Hahn D. 2003. The Tower Menagerie. London: Simon and Schuster.

Hollister N. 1917. Some effects of environment and habit on captive lions. Proceedings of the United States National Museum 53: 177-193.

Jardine W. 1834. The naturaliat's library, Mammalia, Vol. II, the Felinae. Edinburgh: W.H. Lizars.

Linnaeus C. 1758. Systema Naturae per regna tria naturae, secundum classis, ordines, genera, species cum characteribus, differentiis, synonymis, locis. Tenth ed. Vol. 1: 41. Laurentii Salvii, Stockholm, $824 \mathrm{pp}$.

Lopez JV, Culver M, Stephens JC, Johnson WE, O'Brien SJ. 1997. Rates of nuclear and cytoplasmic mitochondrial DNA sequence in mammals. Molecular Ecology and Evolution 14: 277-286.

Nowell K, Jackson P. 1996. Wild cats: status survey and conservation action plan. Gland: IUCN.

O'Regan HJ, Turner A, Sabin RC. 2005. Medieval big cat remains from the Royal Menagerie at the Tower of London. International Journal of Osteoarchaeology 15: 1-10.

Patterson BD. 2004. The lions of Tsavo. New York, McGrawHill.

Shapiro B, Drummond AJ, Rambaut A, Wilson MC, Matheus PE, Sher AV, Pybus OG, Gilbert MTP, Barnes I, Binladen J, Willerslev E, Hansen AJ, Baryshnikov GF, Burns JA, Davydov S, Driver JC, Froese DG, Harington CR, Keddie G, Kosintsev P, Kunz ML, Martin LD, Stephenson RO, Storer J, Tedford R, Zimov S, Cooper A. 2004. Rise and fall of the Beringian steppe bison. Science 306: 1561-1565.

Tabachnick BG, Fidell LS. 2007. Using Multivariate Statistics Fifth Edition. Boston, Pearson.

Yamaguchi N. 2000a. The Barbary lion and the Cape lion: their phylogenetic places and conservation. African Lion News 1: 9-11.

Yamaguchi N. 2000b. The Barbary lion project: its feasibility and potential. African Lion News 2: 12-13.

Yamaguchi N, Driscoll CA, Kitchener AC, Ward JM, Macdonald DW. 2004. Craniological differentiation amongst the European wildcat (Felis silvestris silvestris), the African wildcat (F. s. lybica) and the Asian wildcat (F. s. ornata): implications for their evolution and conservation. Biological Journal of the Linnean Society 83: 47-64.

Yamaguchi N, Haddane B. 2002. The North African Barbary lion and the Atlas Lion Project. International Zoo News 49: 465-481.

Received: 12 July 2007

Accepted: 6 December 2007 


\section{Appendix}

\section{List of craniometric parameters measured}

All measurements are taken from the left side of the skull wherever possible. Numbers and letters in the square brackets are corresponding to those in the Figure. Measurement errors are indicated by coefficient of variation (\%: Mean \pm Standard Error: $N=5,3$ repeats each) in the round brackets.

\begin{tabular}{|c|c|c|}
\hline & Parameter & nt of variation \\
\hline 01 & Cranial volume & $(0.35 \pm 0.084)$ \\
\hline 02 & Frontal breadth [21] & $(0.08 \pm 0.021)$ \\
\hline p & Greatest length [A-B] & $(0.04 \pm 0.012)$ \\
\hline 04 & Condylobasal length $[\mathrm{A}-\mathrm{C}]$ & $(0.03 \pm 0.002)$ \\
\hline 0 & Parlate-inion [V-B] & $(0.14 \pm 0.039)$ \\
\hline o & Nasal-inion [E-B] & $(0.14 \pm 0.035)$ \\
\hline 07 & Facial length $[\mathrm{A}-\mathrm{G}]$ & $(0.17 \pm 0.034)$ \\
\hline 08 & Head length [G-B] & $(0.08 \pm 0.015)$ \\
\hline 9 & Bizygomatic breadth [24] & $(0.04 \pm 0.009)$ \\
\hline 10 & Zygomatic length [K-M] & $(0.11 \pm 0.028)$ \\
\hline 11 & Zygomatic length anterior [K-L] & $(0.30 \pm 0.048)$ \\
\hline 12 & Zygomatic length posterior [L-M] & $(0.31 \pm 0.064)$ \\
\hline 13 & Orbit vertical [4] & $(0.50 \pm 0.195)$ \\
\hline 14 & Orbit horizontal [3] & $(0.94 \pm 0.198)$ \\
\hline 15 & Postorbital bar [2] & $(0.28 \pm 0.043)$ \\
\hline 16 & Facial length anterior $[\mathrm{A}-\mathrm{E}]$ & $(0.59 \pm 0.085)$ \\
\hline 17 & Facial length posterior $[\mathrm{E}-\mathrm{G}]$ & $(0.73 \pm 0.166)$ \\
\hline 18 & Sagittal crest $[\mathrm{H}-\mathrm{B}]$ & $(0.23 \pm 0.064)$ \\
\hline 19 & Cranial height-I [N-H] & $(0.19 \pm 0.027)$ \\
\hline 20 & Cranial height-II [N-H'] & $(0.40 \pm 0.116)$ \\
\hline 21 & Cranial height-III [N-H”] & $(0.33 \pm 0.078)$ \\
\hline 22 & Cranial height-IV $[\mathrm{N}-\mathrm{B}]$ & $(0.34 \pm 0.049)$ \\
\hline 23 & Interorbital breadth [20] & $(0.10 \pm 0.016)$ \\
\hline 24 & Postorbital breadth [22] & $(0.15 \pm 0.073)$ \\
\hline 25 & Nasal length-I [D-F] & $(0.33 \pm 0.144)$ \\
\hline 26 & Nasal length-II [S-F] & $(0.42 \pm 0.202)$ \\
\hline 27 & Nasal breadth [D-D] & $(0.57 \pm 0.110)$ \\
\hline 28 & Breadth between infra orbital foramina [19] & $(0.17 \pm 0.055)$ \\
\hline 29 & Rostral depth-I [1] & $(0.75 \pm 0.140)$ \\
\hline 30 & $\begin{array}{l}\text { Rostral depth-II (E - most posterior end } \\
\text { of canine alveolus) }\end{array}$ & $(0.53 \pm 0.057)$ \\
\hline 31 & Rostral breadth [17] & $(0.16 \pm 0.036)$ \\
\hline 32 & Nasal aperture [18] & $(0.80 \pm 0.448)$ \\
\hline 33 & Upper jaw [A-U] & $(0.10 \pm 0.018)$ \\
\hline 34 & Palate length $[\mathrm{T}-\mathrm{V}]$ & $(0.14 \pm 0.041)$ \\
\hline 35 & Palate breadth-I [29] & $(0.14 \pm 0.034)$ \\
\hline 36 & Palate breadth-II [28] & $(0.16 \pm 0.045)$ \\
\hline 37 & Canine - $\mathrm{Pm}^{4}$ (alveolus - alveolus) & $(0.46 \pm 0.136)$ \\
\hline 38 & $\mathrm{Pm}^{2}-\mathrm{Pm}^{4}$ (alveolus - alveolus) & $(0.25 \pm 0.129)$ \\
\hline 39 & Upper canine height [5] & $(0.36 \pm 0.180)$ \\
\hline 40 & Upper canine diameter antero-posterior [25] & $(0.53 \pm 0.160)$ \\
\hline 41 & Upper canine diameter medio-lateral [26] & $(0.57 \pm 0.171)$ \\
\hline 42 & $\begin{array}{l}\text { Upper canine alveolus diameter } \\
\text { antero-posterior }\end{array}$ & $(1.00 \pm 0.233)$ \\
\hline 43 & $\begin{array}{l}\text { Upper canine alveolus diameter } \\
\text { medio-lateral }\end{array}$ & $(2.02 \pm 0.702)$ \\
\hline 44 & Pm ${ }^{4}$ length [6] & $(0.18 \pm 0.040)$ \\
\hline & $\mathrm{Pm}^{4}$ breadth-I [27] & $(0.83 \pm 0.153)$ \\
\hline 46 & $\mathrm{Pm}^{4}$ breadth -II [27] & $(0.37 \pm 0.092)$ \\
\hline
\end{tabular}

47 Mastoid breadth [23] $\quad(0.04 \pm 0.009)$

48 Skull height-I [W-B] $\quad(0.79 \pm 0.410)$

49 Skull height-II [7] $\quad(0.55 \pm 0.320)$

50 Foramen magnum breadth $\quad(0.16 \pm 0.022)$

51 Foramen magnum height [greatest distance: usually oblique] $\quad(0.65 \pm 0.188)$

52 Occipital condyles breadth [33] $\quad(0.08 \pm 0.043)$

53 Tympanic bulla length [31] $\quad(0.79 \pm 0.137)$

54 Tympanic bulla breadth-I [30] (1.42 \pm 0.559$)$

55 Tympanic bulla breadth-II [32] $\quad(2.96 \pm 1.269)$

56 Mandible length [O-Q] $\quad(0.18 \pm 0.042)$

57 Mandible length coronoid process[O-Q'] $\quad(0.19 \pm 0.058)$

58 Mandible length angular process [O-Q"] $\quad(0.07 \pm 0.019)$

59 Mandible height [13] $\quad(0.23 \pm 0.069)$

60 Mandible height angular process [14] $\quad(0.57 \pm 0.182)$

61 Mandible height coronoid process [15] $\quad(0.16 \pm 0.040)$

62 Maximum width of mandibular condyle [16]

63 Mandible depth-I [11]

64 Mandible depth-II [12]

65 Canine - $\mathrm{M}_{1}$ (alveolus - alveolus)

$66 \mathrm{Pm}_{3}-\mathrm{M}_{1}$ (alveolus - alveolus)

67 Lower canine height [8]

68 Lower canine diameter antero-posterior

69 Lower canine diameter medio-lateral

70 Lower canine alveolus diameter antero-posterior

71 Lower canine alveolus diameter medio-lateral

$72 \mathrm{Pm}_{4}$ length

$73 \mathrm{Pm}_{4}$ breadth (largest breadth usually towards the posterior end)

$(0.08 \pm 0.020)$

$(0.51 \pm 0.237)$

$(0.20 \pm 0.043)$

$(0.27 \pm 0.088)$

$(0.30 \pm 0.077)$

$(1.33 \pm 0.463)$

$(0.78 \pm 0.222)$

$(1.56 \pm 0.290)$

$(1.03 \pm 0.189)$

$(1.72 \pm 0.674)$

$(0.13 \pm 0.022)$

$(0.54 \pm 0.178)$

$(0.95 \pm 0.342)$

$(0.40 \pm 0.117)$

\section{Definitions for the points and measurements in the Figure}

Definitions of general terms are as follows.

Outer Furthest from the mesion

Inner Closest to the mesion

Vertical and Horizontal

These can be defined when a cranium or a mandible(s) is placed in the way shown in the Figure. For the mandible(s), simply place it on a horizontal surface. For the cranium, adjust the cranium to make the surface including the posterior ends of alveoli of both canines and both $\mathrm{Pm}^{4} \mathrm{~s}$ horizontal. 


\section{Definitions for points}

A. Prosthion: the most anterior point of the skull

B. Inion: the most posterior point of the skull

C. The line connecting the most posterior points of occipital condyles

D. The most anterior points of nasals

E. The highest points on the vaults of the anterior ends of dorsal parts of nasals

F. The most posterior point of the inter nasal suture

G. The point where the line connecting the most outer points of postorbital process of frontal meets the mesion

H. Bregma: where the coronal suture meets sagittal suture (if the sagittal crest is very well developed, use the place where the coronal suture reaches the top of the sagittal crest in the mesion)

H' One third distance point between bregma and inion

H" Two third distance point between bregma and inion

I. Vertical lines including the most outer points of the alveoli of $\mathrm{I}^{3} \mathrm{~S}$

J. The most anterior point of alveolus of the upper canine

K. The most dorsal point of infraorbital foramen (in case if there are more than one foramen, the most dorsal point of the foramina)

L. The most outer point of the zygomatic arch (usually just above the malar - temporal suture)

M. A point where a vertical section including the most dorsal point of auditory meatus cuts the outer curve of the zygomatic process of temporal

N. The most dorsal point of auditory meatus

O. Pogonion: the most anterior point of mandible on the inter mandible suture

P. The most ventral point around the angular process. If it is not obvious, use the point where the extended line of the middle line of inferior notch crosses the ventral edge of angular process as being shown in the Figure. This may sound difficult, but in practice there is little problem and a subtle difference of the position of "P" does not seem to affect the result.

Q. The point where the extended line of the ventral end of superior notch crosses the posterior edge of condyle (approximately the middle of condyle)

Q'. The furthest point on the coronoid process from the pogonion

Q". The furthest point on the angular process from the pogonion

R. The line connecting the highest points on the vaults of the anterior ends of dorsal parts of nasals

S. The most anterior point of the inter nasal suture. Often the inter nasal suture of some skulls may be slightly opened towards the anterior end, and it may be difficult to assess where is " $\mathrm{S}$ ". In such case, ignore the part where the inner lines of the nasals forms a sallow angle (almost parallel) to the mesion, and find the point where the angle start to change.

Table S1. A total of 12 clones were sequenced from sample NHM1952.10.20.15, and 10 from NHM1952.10.20.16, and compared to those of Barbary, Indian, and Iranian lions. Only three sequences show evidence of postmortem DNA damage (E4, E6, and F5) and in each instance the damage occurs at nucleotide sites that are not polymorphic in lions.

\begin{tabular}{|c|c|c|c|c|c|c|}
\hline & 1 & 21 & 31 & 41 & 51 & \\
\hline Barbary & СТТАТТСССС & ACGAAAAGCA & AGTGAAAATC & СССААССТСС & ACAGCACAAA & CGCACAATGT \\
\hline India & $\ldots \ldots \ldots$ & $\ldots \ldots \ldots$ & $\ldots \ldots \ldots$ & $\ldots \ldots \ldots$ & $\ldots \ldots \ldots$ & $\ldots \ldots \ldots$ \\
\hline Iran & $\ldots \ldots \ldots$ & $\ldots \ldots \ldots$ & $\ldots \ldots \ldots$ & $\ldots \ldots \ldots$ & $\ldots \ldots \ldots$ & $\ldots \ldots \ldots$ \\
\hline 'C1_1952.10.20.15_Amp1' & $\ldots \ldots \ldots$ & $\ldots \ldots \ldots$ & $\ldots \ldots$ & $\ldots \ldots \ldots$ & $\ldots \ldots \ldots$ & $\ldots \ldots \ldots$ \\
\hline 'G10_1952.10.20.15_Amp1' & $\ldots \ldots \ldots$ & $\ldots \ldots \ldots$ & $\ldots \ldots$ & $\ldots \ldots \ldots$ & $\cdots \cdots \cdots \cdots$ & $\cdots \cdots \cdots$ \\
\hline 'G11_1952.10.20.15_Amp1' & $\ldots \ldots \ldots$ & $\ldots \ldots \ldots$ & $\ldots$. & $\cdots$ & $\cdots$ & $\ldots \ldots \ldots$ \\
\hline 'G12_1952.10.20.15_Amp1' & ... & $\ldots \ldots$ & . & - & & $\cdots$ \\
\hline 'F1_1952.10.20.15_Ämp2' & $\cdots$ & $\cdots$ & . & - & $\cdots$ & \\
\hline 'F3_1952.10.20.15_Amp2' & $\cdots \cdots$ & $\ldots \ldots \ldots$ & & $\cdots$ & & \\
\hline 'F4_1952.10.20.15_Amp2' & $\cdots$ & . & . & .. & - & \\
\hline 'F5_1952.10.20.15_Amp2' & $\ldots$ & $\ldots .$. & $\ldots \ldots \ldots$ & $\ldots . . .$. & . & \\
\hline 'F7_1952.10.20.15_Amp2' & $\cdots$ & $\cdots$ & $\ldots \ldots \ldots$ & $\cdots$ & & \\
\hline 'F8_1952.10.20.15_Amp2' & $\cdots$ & $\cdots$ & $\ldots \ldots \ldots$ & - & $\ldots \ldots \ldots$ & $\cdots$ \\
\hline $.10 .20 .15 \_$Amp2' & $\cdots \cdot$ & $\ldots \ldots \ldots$ & $\ldots \ldots \ldots$ & $\cdots \cdots$ & $\ldots \ldots \ldots$ & $\ldots \ldots \ldots$ \\
\hline 'H12_1952.10.20.15_Amp2' & $\cdots$ & $\ldots \ldots \ldots$ & $\ldots \ldots \ldots$ & $\ldots \ldots \ldots$ & $\ldots \ldots \ldots$ & $\ldots \ldots \ldots$ \\
\hline 'B12_1952.10.20.16_Amp1' & $\ldots \ldots \ldots$ & $\ldots \ldots \ldots$ & $\ldots \ldots \ldots$ & $\ldots \ldots \ldots$ & $\ldots \ldots \ldots$ & $\ldots \ldots \ldots$ \\
\hline $.10 .20 .16 \_$Amp1' & $\ldots \ldots \ldots$ & $\ldots \ldots \ldots$ & $\ldots \ldots \ldots$ & $\ldots \ldots \ldots$ & $\ldots \ldots \ldots$ & $\ldots \ldots \ldots$ \\
\hline .10 .20 .16 Amp1' & ... & $\ldots \ldots \ldots$ & $\ldots \ldots \ldots$ & $\ldots \ldots \ldots$ & $\ldots \ldots \ldots$ & $\ldots \ldots \ldots$ \\
\hline $.10 .20 .16 \_$Amp2' & $\cdots$ & $\ldots \ldots \ldots$ & $\ldots \ldots \ldots$ & $\ldots \ldots \ldots$ & $\ldots \ldots \ldots$ & $\ldots \ldots \ldots$ \\
\hline 'E6_1952.10.20.16_Amp2' & $\cdots$ & $\ldots \ldots \ldots$ & $\ldots \ldots \ldots$ & $\ldots \ldots \ldots$ & $\ldots \ldots \ldots$ & $\ldots \ldots \ldots$ \\
\hline 'E8_1952.10.20.16_Amp2' & & $\ldots \ldots \ldots$ & $\ldots \ldots \ldots$ & $\cdots \cdots \cdots \cdots$ & $\cdots \ldots \ldots$ & $\cdots \cdots \cdots \cdots$ \\
\hline 'E10_1952.10.20.16_Amp2' & $\ldots \ldots \ldots$ & $\ldots \ldots \ldots$ & $\ldots \ldots \ldots$ & $\ldots \ldots \ldots$ & $\ldots \ldots \ldots$ & $\ldots \ldots \ldots$ \\
\hline 'E11_1952.10.20.16_Amp2' & $\cdots$ & $\ldots \ldots \ldots$ & $\ldots \ldots \ldots$ & $\ldots \ldots \ldots$ & $\ldots \ldots \ldots$ & $\ldots \ldots \ldots$ \\
\hline 'E12_1952.10.20.16_Amp2' & $\cdots \cdot \cdot$ & $\ldots \ldots \ldots$ & $\ldots \ldots \ldots$ & $\ldots \ldots \ldots$ & $\ldots \ldots \ldots$ & $\ldots \ldots \ldots$ \\
\hline 'H6_1952.10.20.16_Amp2' & $\ldots \ldots \ldots$ & $\ldots \ldots \ldots$ & $\ldots \ldots \ldots$ & ...N.... & $\ldots \ldots \ldots$ & $\ldots \ldots \ldots$ \\
\hline
\end{tabular}


T. Orale: the point where the line connecting the most posterior points of $\mathrm{I}^{1}$ alveoli meets the mesion

$\mathrm{U}$. The middle point along the posterior part of the alveolus of $\mathrm{M}^{1}$

V. The most posterior point of the palate on the mesion

W. The most ventral point in the mesion between occipital condyles

\section{Definition for measurements}

1. The distance from $\mathrm{R}$ to the most posterior point of the upper canine alveolus

2. The shortest distance between the most dorsal point of the malar - temporal suture and the most ventral edge of the zygomatic arch

3. The distance between the tip of postorbital process of malar and the point where lacrimal - frontal suture crosses the edge of orbit

4. The longest distance between the tip of postorbital process of frontal and the edge of orbit (if the tip of postorbital process of frontal is not pointy enough, use the middle point of the rounded tip)

5. The distance along the buccal surface of an upper canine between the unworn tip and the point on the cemento enamel junction where the medio-lateral breadth of the canine becomes its maximum
6. The distance between the most anterior point of the buccal part of $\mathrm{Pm}^{4}$ and the most posterior point of the tooth

7. The greatest distance between $\mathrm{W}$ and the sagittal crest around its posterior end. In most case, it is easy to measure this distance. However, if the sagittal crest of the skull is very well developed, measure the distance between $\mathrm{W}$ and the sagittal crest around the middle point between $\mathrm{H}$ " and B.

8. The distance along the buccal surface of a lower canine between the unworn tip and the point on the cemento enamel junction where the medio-lateral breadth of the canine becomes its maximum

9. The distance between most anterior and posterior points of $\mathrm{M}_{1}$

10. The distance between the most anterior point of canine alveolus and the most posterior point of $\mathrm{M}_{1}$ alveolus

11. The smallest of the greatest diameter of the section which cuts the mandible in front of the most anterior point of $\mathrm{Pm}_{3}$ alveolus: usually an oblique measurement like the one shown in the Figure

12. The smallest of the greatest diameter of the section which cuts the mandible just behind the most posterior point of $\mathrm{M}_{1}$ alveolus: usually a vertical or slightly oblique measurement shown in the Figure

13. The greatest distance between $\mathrm{P}$ and the dorsal part of coronoid process

14. The greatest distance between $P$ and the dorsal part of condyle just outside the place where superior notch

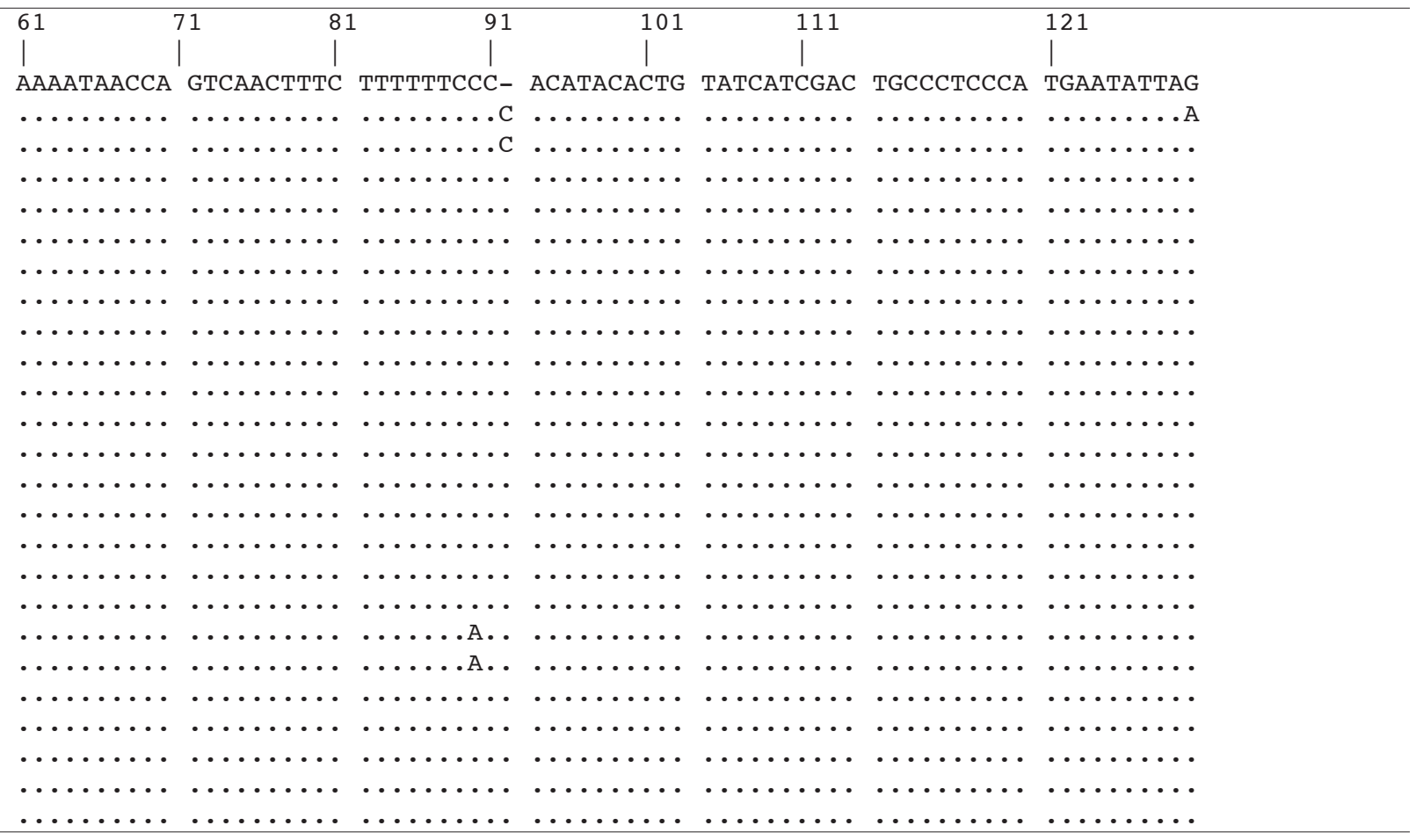


crosses the condyle: usually an oblique measurement shown in the Figure

15. The greatest distance between the ventral part of condyle just inside the place where the condyle meets inferior notch and the dorsal part of coronoid process: usually an oblique measurement shown in the Figure - in most cases use the point on the coronoid process that was used to measurement 13

16. Maximum width of mandibular condyle

17. The greatest breadth of the rostrum just above the canine alveoli

18. The breadth of nasal aperture above the most outer points of $\mathrm{I}^{3}$ alveoli

19. The smallest distance between infraorbital foramina

20. Interorbital breadth: the smallest distance between the orbits

21. The distance between the most outer points of postorbital process of frontal

22. Postorbital breadth: the smallest breadth of the postorbital constriction

23. Mastoid breadth: the distance between the most outer points of mastoidal processes

24. The distance between zygions: the most outer points of zygomatic arches

25. The greatest antero-posterior length of an upper canine at the cemento-enamel junction: the greater diameter of the canine

26. The greatest medio-lateral length of an upper canine at the cemento-enamel junction: the smaller diameter of the canine

27. $\mathrm{Pm}^{4}-\mathrm{I}$ : between the inner process and the most anterior outer process, and $\mathrm{Pm}^{4}$-II: between the former and the second most anterior outer process of the tooth

28. The smallest distance between $\mathrm{M}^{1}$ alveoli

29. The greatest distance between $\mathrm{Pm}^{4}$ alveoli

30. The distance between the most anterior/ inner meeting point between tympanic bulla and external auditory meatus and the most anterior meeting point between tympanic bulla and foramen lacerum posterius

31. The greatest length of tympanic bulla excluding styloid process and other processes attached to the tympanic bulla: fix one end of the caliper at the point where foramen lacerum medius meets the most prominent styloid process, and measure the greatest distance between that point and the posterior part of the tympanic bulla

32. The greatest mediolateral distance of the vault of the tympanic bulla: the smaller diameter of the vault of the tympanic bulla

33. The greatest breadth of occipital condyles

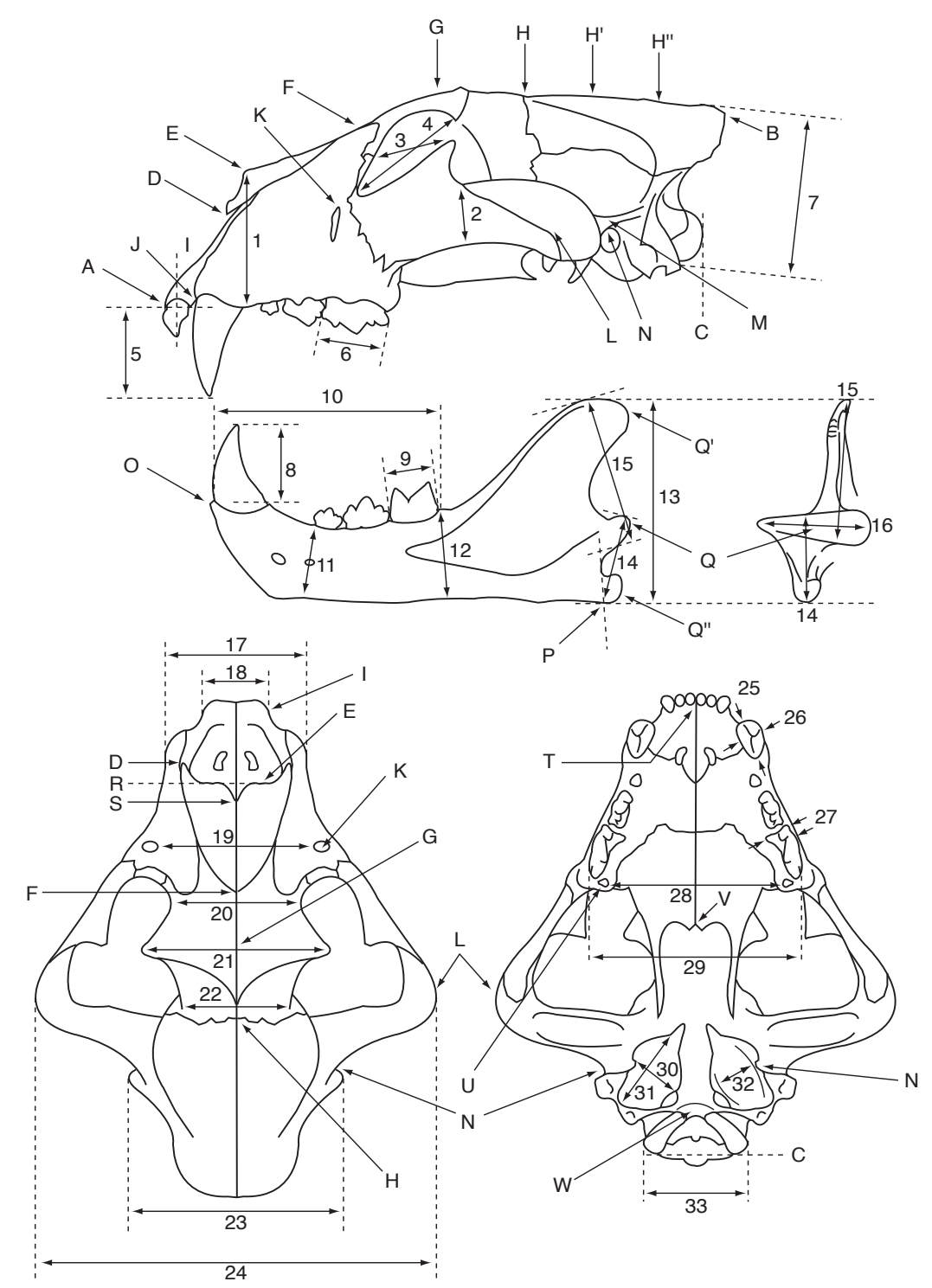

